\title{
trabalnenecessário
}

issn: $1808-799 \mathrm{X}$

ano 4 - número 4 - 2006

\section{As relações Sociais de Produção Artística e o Ensino de ARTE}

EDITH FRIGOTTO

\section{RESENHA}

O livro Educação e Estética. Ensaios sobre Arte e Formação Humana no Pósmodernismo, de Ronaldo Rosas Reis (Editora Cortez, 2005, 128 p.) traz uma contribuição significativa para as questões educacionais na sua relação pouco explorada com as questões estéticas e suas condições de produção, enquanto materialidade que ocupa os espaços políticos disputados na construção de significados das relações sociais. A produção teórica relacionando arte e trabalho ainda é incipiente no próprio campo de Trabalho e Educação, cujo foco predominante tem sido as mudanças da base técnica do trabalho e dos processos produtivos e as perspectivas conflitantes ou antagônicas do papel da educação face a essas mudanças. Indica, portanto, as "possibilidades investigativas que a educação estética oferece" para este campo.

Trata-se de uma análise crítica no seu sentido mais desvelador das sublimações que se possa fazer da produção estética, ao mesmo tempo em que insere a produção artística no processo de formação cultural do ser humano, não como um evento singular de grupos implicados na produção artística, mas como parte orgânica da materialidade de produção da existência, em que a arte expressa e refrata as tensões das relações sociais, assim como a disputa por concepções e espaços políticos.

Embora demonstre em todo o texto o esforço das elites em "monologizar" o significado da arte em épocas distintas, a partir da diluição das tensões e dos conflitos em prol da celebração, em alguns momentos do já estabelecido (como as Belas-Artes), e em outros momentos da efemeridade do novo como indício de superação de posturas perturbadoras, o autor focaliza a vitalidade própria da Arte em constante inquietação.

Por isso, o autor "convencido da importância do conhecimento estético na formação humana..." nos oferece um livro que recupera, desde a fundação da pólis grega, a importância do olhar filosófico e artístico como elementos de compreensão da organização das relações sociais, chegando à produção cinematográfica brasileira e sua dificuldade de se estabelecer em função da lógica cultural capitalista, que repercute na falta de uma política de formação de habitus de fruição de bens culturais nacionais pela ausência de uma 
continuidade na sua produção, negando, assim, a participação da sociedade no conhecimento do saber do cinema.

O título "Educação e Estética" já denuncia o falso paralelismo entre as duas áreas, mas que a partir da leitura do livro vão se articulando, senão pela própria explicitação da natureza das mesmas, pelo horizonte de possibilidades em assumir a dimensão estética como mediação cultural na formação de crianças e jovens HUMANA. Nesse sentido a reflexão sobre a arte deve considerar, como afirma Bayer (2000) que os valores estéticos não se encontram isolados, mas são também expressões dos valores morais e políticos. $\mathrm{E}$, como reitera ao longo desta obra, valores estéticos, morais e políticos são socialmente produzidos.

Artista plástico, educador, pesquisador, Ronaldo Reis tece, a partir de seus estudos, uma trama conceitual que aos poucos vai esclarecendo as ligações entre os textos que ele escolheu para fazer parte desta publicação. Habituado a operar com os vários conceitos de estética desde as suas propensões artísticas pessoais até a sua formação, o autor transita naturalmente pela intrincada complexidade que a área produziu.

O livro situa historicamente o papel da arte na construção de subjetividades, assim como analisa a arte como trabalho na expressão estética de diferentes linguagens.

As questões estéticas ocuparam um espaço significativo no sistema filosófico europeu, e mais especificamente no idealismo alemão em cujo berço foi possível sistematizar o conceito de totalidade expresso como um enorme potencial heurístico capaz de devolver à natureza humana, principalmente ao cindido burguês do século XVIII, seu sentimento de integralidade. Segundo Reis, "Baudellaire e Zola dirigiam advertências tanto à elite burguesa quanto aos artistas sobre a necessidade de se construir uma visão de mundo fundada na dialética Razão e Sensibilidade".

Essa concepção filosófica da estética teve como conseqüência uma produção artística inovadora capaz de incorporar à arte uma tecnicalidade antes estranha ao seu universo. Se por um lado essa fusão dialética abre caminhos para a compreensão da totalidade da natureza humana, por outro, fornece munição à incorporação da arte como um artefato a mais produzido no mercado.

Entretanto, o papel revolucionário da arte, o olhar trágico do artista que desestabiliza acaba por se submeter a uma normatização alheia ao processo singular de criação. Estaríamos diante de uma estética conformada, empobrecida, quase encomendada? Seria a morte da arte? Teria a arte perdido sua relevância social, e assumido apenas seu valor de mercadoria no contexto atual?

Os diferentes movimentos de vanguarda dos quais nos fala o autor demonstram de um lado a vitalidade do artista, de outro uma busca ontológica de sua identidade. $\mathrm{O}$ movimento de "Retorno à pintura", por exemplo, expressa concepções contraditórias. Em alguns momentos, o conceito de criatividade submerso nas demandas da lógica de mercado 
desconfigura a função social da arte como capacidade de expressão da sensibilidade humana na busca do seu auto-conhecimento.

A primeira parte do livro estabelece um eixo analítico situando a dimensão estética como elemento de problematização da história cultural, apontando em diferentes épocas sua trajetória histórica de busca por uma identidade no confronto com as tentativas de captura pela lógica capitalista de sua especificidade e seu potencial heurístico e transformador.

Articulando a esse mapeamento inicial, o autor procede, na segunda parte do livro, a uma análise do contexto sócio-político em que o Brasil passa a consumir oficialmente concepções e práticas artísticas européias e a tutelar, legitimando, a produção. Esse passado histórico se atualiza numa certa imposição de gosto estético avesso ao potencial criativo das novas linguagens.

Neste sentido é essencial para a formação de educadores a análise que faz das concepções teóricas que fundamentam os Parâmetros Curriculares Nacionais, demonstrando a sua parcialidade por não levar em conta a explicitação do cenário histórico em que os conceitos, que balizam esse documento-proposta, foram produzidos. Embora os Parâmetros reconheçam a arte como um campo específico de organização do conhecimento, não explicitam a gênese dos conceitos que alicerçam as propostas de ArteEducação.

Vale ressaltar ainda, a recorrente denúncia que faz sobre o drama do existir não existir da arte brasileira em função da valorização espasmódica dessa produção e a conseqüente ausência de uma tradição de visualidade na formação cultural desenvolvida pela escola.

Este, portanto, é um livro que, pela originalidade da abordagem sobre arte e educação pela densidade e abrangência em que a análise a situa, torna-se uma referência obrigatória tanto para os que atuam na área de educação quanto, mais amplamente, para professores e estudantes de graduação e pós-graduação de ciências sociais e humanas. 